\title{
O PERCURSO METODOLÓGICO,DE UMA PESQUISA NO AMBIENTE PRISIONAL NA ÁREA DE CIÊNCIA DA INFORMACÁO: limites e potencialidades da Etnografia
}

\author{
THE METHODOLOGICAL PATH OF RESEARCH IN THE PRISON \\ ENVIRONMENT IN THE AREA OF INFORMATION SCIENCE: \\ limits and potentialities of the Ethnography
}

Ciro Athayde Barros Monteiro ${ }^{1}$

\begin{abstract}
RESUMO
A etnografia é uma abordagem metodológica essencial para compreender as demandas sociais do campo da Ciência da Informação e pode ser utilizada em diversos ambientes, dentre eles, na prisão. 0 objetivo deste artigo é expor o percurso metodológico que trilhei no interior da prisão ao realizar pesquisa de campo para o desenvolvimento da tese "Informação encarcerada: o jovem da 'geração internet' e a mediação e apropriação dos dispositivos informacionais no interior da prisão" utilizando a etnografia como metodologia de pesquisa qualitativa dentro do escopo da Ciência da Informação (CI). Neste artigo, apresento alguns conceitos e reflexões acerca das potencialidades e dos limites desta metodologia e relato os caminhos que percorri para coletar os dados, detalhando como foi a escolha do universo, a aplicação dos instrumentos de pesquisa, os questionamentos que surgiram ao longo do estudo, a seleção dos sujeitos e os desafios para realizar a pesquisa. A descrição do percurso metodológico apresenta ao leitor as possibilidades de utilização da etnografia, tanto na prisão quanto nos demais ambientes que despertem o interesse da área. No caso específico da prisão, o uso da etnografia foi bastante significativo, revelando-se flexível, dotado de mecanismos de registro e apreensão das subjetividades, capaz de fazer um mergulho interpretativo no universo de pesquisa. Além disso, esta metodologia proporciona uma constante renovação do olhar acerca da episteme da área e de suas formas de atuação social.
\end{abstract}

Palavras-chave: Etnografia. Metodologia. Biblioteca Prisional. Dispositivos e Ciência da Informação

\section{ABSTRACT}

Ethnography is an essential methodological approach to understand the social demands of the field of Information Science and can be used in different environments, among them, in prison. The aim of this article is to expose the methodological path that I followed inside the prison when conducting field research for the development of the thesis "Incarcerated information: the young man of the 'internet generation' and the mediation and appropriation of informational devices inside the prison" using ethnography as a qualitative research methodology within the scope of Information Science $(\mathrm{Cl})$. In this article, I present some concepts and reflections about the potential and limits of this methodology and report the paths I took to collect the data, detailing how the universe was chosen, the application of the research instruments, the questions that arose throughout the study, the selection of the participants, and the challenges to carry out the research. The description of the methodological path presents the reader with the possibilities of using ethnography, both in prison and in other environments that arouse the interest of the area. In the specific case of prison, the use of ethnography was quite significant, proving to be flexible, with mechanisms for registering and apprehending subjectivities, capable of making an interpretive dive into the universe of research. In addition, this methodology provides a constant renewal of view regarding the area's episteme and its forms of social action.

Keywords: Ethnography. Methodology. Prison Library. Devices and Information Science

Artigo submetido em 21/07/2020 e aceito para publicação em 09/08/2020

1 Doutor pelo Programa de Pós-Graduação em Ciência da Informação. Universidade Estadual Paulista Julio de Mesquita Filho, Brasil. ORCID http://orcid.org/0000-0003-0673-7516.E-mail: cirocosmos@gmail.com 


\section{INTRODUÇÃO}

Ao iniciar uma pesquisa com a temática envolvendo o sistema carcerário e pessoas encarceradas, dentro do escopo da Ciência da Informação $(\mathrm{Cl})$, uma das principais questões que saltou aos meus olhos foi sobre como realizá-la, como superar os limites que separam realidades tão distantes e quais métodos e ferramentas utilizar para ao menos minimizar o distanciamento desses mundos e da vida entre muros.

Essas dúvidas e questionamentos me acompanharam durante quase todo processo de desenvolvimento da tese "Informação encarcerada: o jovem da geração internet e a mediação e apropriação dos dispositivos informacionais no interior da prisão", a qual teve como tema a apropriação que os jovens de 18 a 20 anos fazem dos dispositivos informacionais (biblioteca, clube de leitura, etc.) antes e após entrarem no cárcere. Tal assunto surgiu a partir da constatação de que a maioria dos pesquisadores da área de Ciência da Informação utilizam o termo "sociedade da informação" (SI) de forma acrítica, como se principalmente os jovens fizessem parte de uma "geração internet" em que todas as pessoas ou grupos sociais seriam membros de uma geração que sabem lidar facilmente com tecnologias.

A partir desse problema e questionando se os jovens encarcerados seriam membros dessa dita "sociedade da informação", o objetivo do estudo foi investigar as práticas informacionais desses jovens encarcerados no Centro de Detenção Provisória de Serra Azul - São Paulo com relação à mediação e apropriação dos dispositivos informacionais disponíveis. Para isso, foi necessário encontrar um método capaz de fazer um mergulho interpretativo na prisão e perceber os detalhes, discursos e comportamentos que atravessam o espaço prisional.

Ainda que eu tenha sido, durante nove anos, funcionário do setor de educação no sistema penitenciário que convive diariamente com os detentos e pesquisador que mantêm observações guiadas pela pergunta de pesquisa em relação ao seu objeto, a relação preso-funcionário é totalmente hierárquica. Sou funcionário da prisão e para eles represento várias possibilidades, tanto alguém que possa levar algo, como por exemplo, informações sobre a sua pena, sobre o rol de visitas ou disponibilizar livros e cursos, como alguém que possa "castigá-los" caso eles façam algo que contrarie os parâmetros de comportamento previstos na lei de execução penal, ou àqueles referente às regras internas de funcionamento da prisão.

Nesse sentido, para ilustrar o início deste artigo, cito um trecho da música "0 destino do réu" do rapper Dexter que ficou 13 anos preso, e que narra um pouco da sua vida no sistema prisional. No trecho, 
o músico diz "passei o final de semana na inclusão, só de reflexão, sem rádio, sem televisão, ouvindo histórias contadas por alguém, Monteiro Lobato na cadeia é o que mais tem" (DEXTER, 2016). Este tipo de vivência "passar o final de semana na inclusão", ou seja, ficar em uma cela da prisão sem nenhum meio de comunicação, o pesquisador/funcionário não é capaz de experimentar, tendo em vista que como agente penitenciário minha função é receber os presos, providenciar assistência material que garanta necessidades básicas, vestuário, etc., porém é o educando que vai passar o final de semana em uma cela.

Esse é o limite em questão o qual nenhum método consegue romper, e é apontando esses limites que justifico a necessidade de escrever este artigo, ou seja, narrar como foi trabalhar com o método etnográfico no interior da prisão e demonstrar de que maneira a etnografia pode ser um olhar essencial para que as atividades e os espaços de leitura sejam observados de forma mais sistemática pelos pesquisadores da Ciência da Informação, ampliando o escopo do campo e o leque de possibilidades para atuação do profissional bibliotecário no interior da prisão.

Com o objetivo de descrever e identificar a relevância da etnografia como abordagem metodológica no ambiente prisional no campo da $\mathrm{Cl}, 0$ artigo descreve como foi a aplicação dos instrumentos no interior da prisão. Além disso, discorro sobre o percurso de desenvolvimento e aplicação do estudo, a escolha da etnografia como metodologia e os inúmeros questionamentos que surgiram ao longo da coleta e análise de dados, sobre a preferência do universo de pesquisa e os motivos pelos quais optei por um Centro de Detenção Provisória em detrimento de uma Penitenciária. Abordo a questão da seleção dos sujeitos de pesquisa, dos desafios para realizar as entrevistas e anotações, e da importância da orientação teórica interacionista de Goffman como ferramenta de análise e coleta de dados.

\section{ETNOGRAFIA E OS LIMITES DO MÉTODO NO INTERIOR DA PRISÃO}

Para Geertz, fazer etnografia “[...] é como tentar ler um manuscrito estranho, desbotado, cheio de elipses, incoerências, emendas suspeitas e comentários tendenciosos, escritos não com sinais convencionais do som, mas com exemplos transitórios de comportamento modelado" (GEERTZ, 2015, p.07). Esse “manuscrito estranho" citado por Geertz, o qual está desbotado, cheio de emendas, comentários tendenciosos e é difícil de ler, é exatamente a realidade que encontrei ao tentar entender ou registrar o funcionamento e os relacionamentos estabelecidos no interior da prisão. Em um ambiente que, mesmo submetido à legislação e aos próprios regimentos, tem suas regras internas de funcionamento que são estabelecidas diariamente na relação do preso com o funcionário e o sistema. 
Essas regras não são fáceis de serem percebidas tanto para um "outsider" como para um "infiltrado" (alguém que trabalhe diariamente na prisão), e talvez o método que mais se aproxime da possibilidade de adentrar a este mundo seja a etnografia, na medida em que se propõe a tentar compreender as pessoas reais e suas realidades concretas.

Grosso modo, a etnografia pode ser definida como "[...] a arte e a ciência de descrever um grupo humano - suas instituições, seus comportamentos interpessoais, suas produções materiais e suas crenças" (ANGROSINO, 2009, p.30). 0 método pressupõe que o pesquisador entre em contato com 0 universo de pesquisa e que possa comparar as teorias e sair com um novo modelo de entendimento (MAGNANI, 2009, p.135).

Esse novo entendimento proporcionado pela prática da etnografia no universo de pesquisa é próprio do método de trabalho da antropologia no sentido amplo e não pode ser confundido nem reduzido a uma técnica ou experiência de campo. 0 conjunto de técnicas empregados nas estratégias de campo, como por exemplo, observação participante, entrevista, entre outras, devem estar vinculados a escolhas teóricas e acompanhado de uma discussão conceitual. Além disso, é importante refletir acerca da objetividade científica na etnografia.

Um pensador que ilustra bem a ideia de objetividade científica e seus paradoxos é o pesquisador polonês Bronislaw Malinowski, cuja contribuição não só à etnografia como para ciência são notáveis. Fruto de seu tempo, porém contestador de modelos como a visão romântica e as especulações evolucionistas, Malinowski foi grande defensor da pesquisa de campo e do que viria a ser conhecido como observação participante. Por ter permanecido quatro anos em seu campo de pesquisa, nas ilhas de Trobriand, devido a complicações internacionais causadas pelas condições da Primeira Guerra Mundial, o pesquisador trouxe significativas contribuições à área social, principalmente à então nascente antropologia social.

Em seu clássico livro "Argonautas do Pacífico", publicado em 1922 e considerado precursor da etnografia e do uso etnográfico da fotografia, o autor relata que "[...] os resultados de uma pesquisa científica devem ser apresentados de maneira totalmente neutra e honesta" (MALINOWSKI, 1978, p.18). Essa afirmação de que os resultados de uma pesquisa devem ser apresentados de maneira totalmente "neutra e honesta", representa o modelo positivista de objetividade que tornou-se um paradigma na ciência e influenciou grande parte das pesquisas do início do século XX e que, como afirma autores como Carlos Alberto Ávila Araújo (ARAUJO, 2009, p.203), continua influenciando a Cl. 
Malinowski contribuiu significativamente com o campo, porém escreveu no início do século XX e recebeu influências de sua formação nas ciências exatas, além de ter sido considerado um dos fundadores do funcionalismo. Nesse sentido, é possível compreender 0 autor de acordo com 0 seu tempo, todavia a ideia de "neutralidade" deve ser sempre questionada na ciência. Concordo com a opinião de Scott, quando afirma que as etnografias prisionais não podem ser isentas de valores:

As etnografias prisionais não podem ser objetivas, neutras ou isentas de valores (...) Os pesquisadores devem estar preparados para confessar seu ponto de vista, reconhecendo abertamente seus valores (...) A pesquisa nunca pode ser isenta de valores. Nem deveria ser. No centro do processo de pesquisa está o esclarecimento e justificação dos valores adotados (SCOTT, 2016, p. 197, tradução nossa)

Nessa perspectiva, é necessário desconstruir a ideia de "neutralidade" e "objetividade" amplamente contemplado pelo discurso científico, pois, por meio das observações feitas acerca das palavras de Malinowski é possível perceber que a cultura molda os pontos de vista e que as coisas são percebidas pelos nossos sentidos e esses não são absolutos: "Temos de lembrar, no entanto, que a objetividade de nossos cinco sentidos não é absoluta. Todos nós tendemos a perceber as coisas através de filtros; algumas vezes esses filtros fazem parte intrínseca do método de pesquisa" (ANGROSINO, 2009, p.56).

Nesse sentido, ao etnógrafo não é possível operar com certeza objetiva, embora ele possa se esforçar pela busca da exatidão, deve ter em mente que seu olhar está lambuzado de valores e intenções. Além disso, o olhar do observador pode ser manipulado tanto pelos informantes, como pelo deslumbre de entrar em um lugar desconhecido. A pesquisadora Camila Dias, ao adentrar em um presídio e observar os procedimentos de segurança feito pelos funcionários da prisão no momento em que encaminhavam os presos ao local em que seriam entrevistado, ou seja, uma sala próxima ao portão principal da unidade, fez a seguinte consideração:

Decorrente desse mesmo problema de a sala ser próxima ao portão principal da unidade era a necessidade de algemas nos pés e nas mãos dos presos que vinham para a entrevista. A imposição desse procedimento de segurança para todos os presos que tivessem acesso a esse local me causou um enorme mal-estar na medida em que a colaboração com a pesquisa acabava por expor esses indivíduos a uma situação extremamente vexatória, vindo algemados desde 0 interior da unidade, passando pelo longo corredor do prédio administrativo conduzidos por um funcionário da mesma maneira que se conduz um animal feroz que se acaba de caçar (DIAS, 2011, p.39).

Nas palavras da pesquisadora Camila Nunes a problemática dos valores no olhar do etnógrafo fica evidente. Como o (a) leitor (a) já sabe, sou funcionário da prisão há nove anos e nesse período vivenciei situações de fuga ou tentativa de fuga dos presos por falta de algemação. Aos meus olhos, 
mesmo com todo controle de emoções e necessidade de se despojar dos preconceitos que o método e a aplicação da técnica exigem, dificilmente consigo ter os olhos de um "etnógrafo deslumbrado" em que se atinge 0 ideal da observação, o qual o observador quando entra no cenário de campo faz o possível para pôr de lado os preconceitos e se torna uma "criancinha para quem tudo é novo" (ANGROSINO, 2009, p.57).

Do ponto de vista da pesquisadora, algemar os presos nos pés e nas mãos para se deslocarem até a entrevista foi um procedimento vexatório e causou constrangimento tanto para os presos como para a pesquisadora, que relatou sentir mal-estar com a situação. Além disso, para ela o preso era conduzido pelo funcionário da prisão como "um animal feroz que se acaba de caçar".

Aos olhos do funcionário, o procedimento descrito pela pesquisadora de algemação do preso é uma conduta usual de cadeia. 0 agente penitenciário está preocupado em evitar que a entrevistadora fique de refém em uma rebelião, ou qualquer outra anormalidade, como por exemplo, agressão, tentativa de fuga, ou tentativa de tornar o funcionário refém, como aconteceu recentemente em um Centro de Detenção do interior paulista e o preso só não obteve êxito porque estava algemado e os funcionários conseguiram imobilizá-lo. Ocorrência que não teve repercussão midiática.

Essas problemáticas são interessantes e me faz refletir cotidianamente acerca da prática etnográfica e de como o fato de conhecer previamente os sujeitos (não os sujeitos que participaram da pesquisa, mas a forma usual de comportamento estabelecida no sistema) e 0 universo de pesquisa pôde influenciar na minha coleta de dados. Conhecer os sujeitos e estar cotidianamente entre eles, mesmo que guiado pelas perguntas de pesquisa, tem pontos positivos e negativos. Os positivos é que o pesquisador sabe lidar com as situações e filtrar o que é realmente importante para tomar nota. 0 negativo é que existe a diminuição do "estranhamento", e consequentemente não sou capaz de fazer algumas observações que seriam feitas por um observador em que o ambiente é desconhecido, como tomar nota de tudo, avaliar tudo como significativo e digno de registro, tentando se dispor de hierarquias de valores.

No entanto, o cuidado para que o "estranhamento" e o "olhar antropológico" estejam sempre presentes é essencial, tendo em vista que a simples convivência com os sujeitos de pesquisa não é pressuposto necessário para efetuar uma coleta de dados adequada (ROMANELLI, 1998, p.123). Esse processo de "estranhar o que é familiar" é realmente transformador e fez com que minha conduta, mesmo que influenciada pela experiência de funcionário, fosse sempre vigiada pelo olhar antropológico e pelo conhecimento teórico. Tentei ao máximo me reportar aos princípios teóricos da etnografia, 
mesmo admitindo as influências que minha rotina na prisão trouxe no processo de coleta e análise dos dados.

As barreiras de acesso e os limites dos instrumentos de pesquisa faz com que o método etnográfico receba contornos peculiares durante sua prática na prisão, sendo necessário o esforço intelectual e a base teórica da antropologia para que seja possível efetuar a pesquisa e enfrentar as barreiras. Esse esforço intelectual do etnógrafo é responsável por definir o empreendimento, tendo em vista que o método não se reduz a técnicas e processos determinados (GEERTZ, 2015, p.4).

De acordo com Geertz, diferentemente da perspectiva funcionalista extremamente vinculada a técnica, elaborar uma etnografia a partir de uma "descrição densa" consiste em interpretar e elaborar uma leitura da leitura que os nativos fazem da própria cultura. Segundo o autor, o que o etnógrafo enfrenta "[...] é uma multiplicidade de estruturas conceituais complexas, muitas delas sobrepostas ou amarradas umas às outras, que são simultaneamente estranhas, irregulares e explícitas" (GEERTZ, 2015, p.7).

Essa etnografia interpretativa enquanto método de pesquisa tem a função não apenas de guiar o pesquisador em campo, mas é responsável por delinear o papel do antropólogo sem a necessidade dele se tornar um nativo, ou seja, o objeto de estudo. Para o autor, o etnógrafo "inscreve" o discurso social: ele 0 anota. Isso significa que ao registrar o discurso, "ele o transforma de acontecimento passado, que existe apenas em seu próprio momento de ocorrência, em um relato que existe em sua inscrição e que pode ser consultado a qualquer momento" (GEERTZ, 2015, p.14).

Essa possibilidade de interpretar o discurso após sua inscrição e fazer o exame crítico, é essencial para compreensão da descrição densa defendida por Geertz, que está embasada em três características que se fundamentam em uma: ser interpretativa, ou seja, ela "[...] é interpretativa; o que ela interpreta é o fluxo do discurso social; e a interpretação envolvida consiste em tentar salvar o dito num tal discurso da sua possibilidade de extinguir-se e fixá-lo em formas pesquisáveis" (GEERTZ, 2015, p.15). Nesse sentido, na concepção de Geertz, ao realizar um trabalho etnográfico, o pesquisador não só marca o seu posicionamento, como Ihe é concedido a possibilidade de realizar uma compreensão que os nativos têm de suas interpretações, sendo possível uma leitura de segunda ou terceira mão, na medida em que para 0 autor apenas o próprio nativo faz leitura de primeira mão.

Essa perspectiva vai ao encontro do que estou apontando desde o início deste texto, sendo as concepções de Geertz essenciais para compreensão da base teórica que guiou este artigo, pois ao apontar os limites do método etnográfico o coloco necessariamente como "interpretativo", muitas vezes 
de terceira mão; "crítico", leva o pesquisador a pensar constantemente o lugar da fala; e "microscópico", 0 antropólogo aborda conhecimentos extensivos a partir de assuntos extremamente pequenos.

Esse mergulho interpretativo do pesquisador no campo, permite que ele saia com um novo olhar, um novo arranjo que não é mais o nativo e nem aquele com o qual iniciou a pesquisa:

[...] a natureza da explicação pela via etnográfica tem como base um insight que permite reorganizar dados percebidos como fragmentários, informações ainda dispersas, indícios soltos, num novo arranjo que não é mais 0 arranjo nativo (mas que parte dele, leva-0 em conta, foi suscitado por ele) nem aquele com 0 qual o pesquisador iniciou a pesquisa. Este novo arranjo carrega as marcas de ambos: mais geral do que a explicação nativa, presa às particularidades de seu contexto, pode ser aplicado a outras ocorrências; no entanto, é mais denso que o esquema teórico inicial do pesquisador, pois tem agora como referente o "concreto vivido" (MAGNANI, 2002, p.17).

Essa é a grande contribuição que a etnografia traz para a ciência e para a sociedade, ou seja, esse novo olhar tendo como referente 0 concreto vivido. Um olhar que busca a contradição do de "perto e de dentro" com o "de fora e de longe", em que seja possível "[...] resgatar um olhar de perto e de dentro capaz de identificar, descrever e refletir sobre aspectos excluídos da perspectiva daqueles enfoques que, para efeito de contraste, qualifiquei como de fora e de longe" (MAGNANI, 2002, p.17).

Nesse sentido, neste artigo faço um mergulho interpretativo no ambiente prisional, descrevendo os detalhes por meio do meu ponto de vista, pois como relata Leonardo Boff no livro "A Águia e a Galinha": "Ler significa reler e compreender, interpretar. Cada um lê com os olhos que tem. E interpreta a partir de onde os pés pisam. Todo ponto de vista é a vista de um ponto" (BOFF, 1998, p. 9).

\section{CENTRO DE DETENÇÃO PROVISÓRIA: 0 UNIVERSO DE PESQUISA ESCOLHIDO}

Atualmente 0 Estado de São Paulo possui 176 unidades prisionais, sendo 87 Penitenciárias (PEN), 48 Centros de Detenção Provisória (CDP), 15 Centros de Progressão Penitenciária (CPP), 22 Centros de Ressocialização (CR), 01 Regime Disciplinar Diferenciado (RDD) e 03 Hospitais de Custódia $(\mathrm{HC})$.

Segundo dados de dezembro de 2019 do Departamento Penitenciário Nacional (DEPEN), são 231.287 sentenciados paulistas de uma população prisional brasileira de 748.000 em que 0 estado de São Paulo concentra a maior população prisional do país com 33\% dos sentenciados brasileiros. 0 universo escolhido para realizar a pesquisa é um lugar "microscópico", para usar o termo de Geertz, um Centro de Detenção Provisória. Parte significativa dessa população é constituída por jovens, negros e pessoas com baixa escolaridade. 
Diante do enorme desafio para escolher o universo de pesquisa dentre as inúmeras possibilidades de realizá-la, na medida em que existem jovens em todos os tipos de regimes penais e unidades prisionais, escolhi um Centro de Detenção Provisória, mais especificamente a unidade de Serra Azul. Antes de detalhar suas características e especificidades, demostro, por meio de imagens ilustrativas, como é um Centro de Detenção Provisória (CDP) no Estado de São Paulo.

Figura 1 - Centro de Detenção Provisória

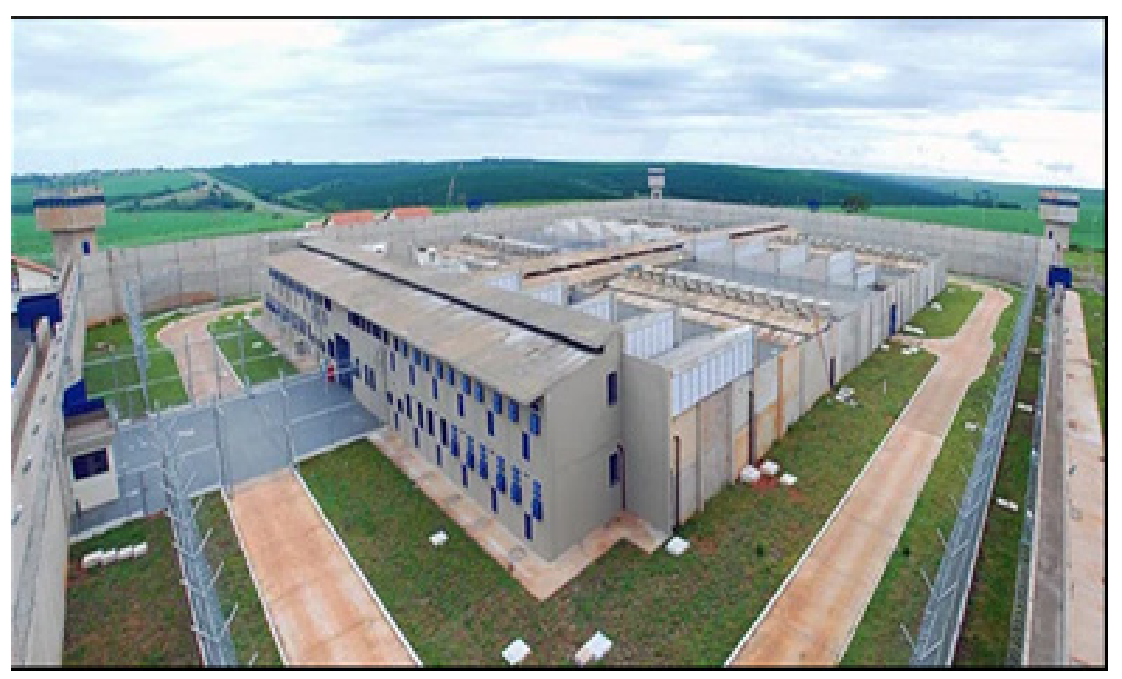

FONTE: Secretaria de Administração Penitenciária

0 CDP é um modelo de unidade prisional de regime fechado. Possui capacidade para 847 presos, parlatório de salas de audiência, detectores de metais e sistema de alarme, atendimento médico e odontológico (alguns com restrições devido à falta de funcionários), pavilhão de trabalho, e é construído para abrigar presos provisórios, ou seja, presos que aguardam julgamento. Além disso, possui salas de aula, biblioteca e cozinha.

São oferecidas aulas do ensino fundamental ao médio, ministradas pelos professores da Secretaria de Educação, no formato Educação de Jovens e Adultos (EJA) no período diurno. Todos os presos que ainda não concluíram o ensino regular podem participar das aulas. Além disso, todos os cursos como, por exemplo, Programa de Educação para o Trabalho (PET) e cursos profissionalizantes acontecem no espaço escolar, exceto curso de panificação que acontece na cozinha.

A distribuição de livros no CDP é feita por meio de um carrinho, guiado pelo funcionário, que entra nos pavilhões quando as celas estão fechadas e os presos trancados. 0 educando não possui acesso direto à biblioteca e a escolha dos livros é feita por meio de um catálogo que circula nas celas. 
Figura 2 - Cozinha/Galpão de Trabalho
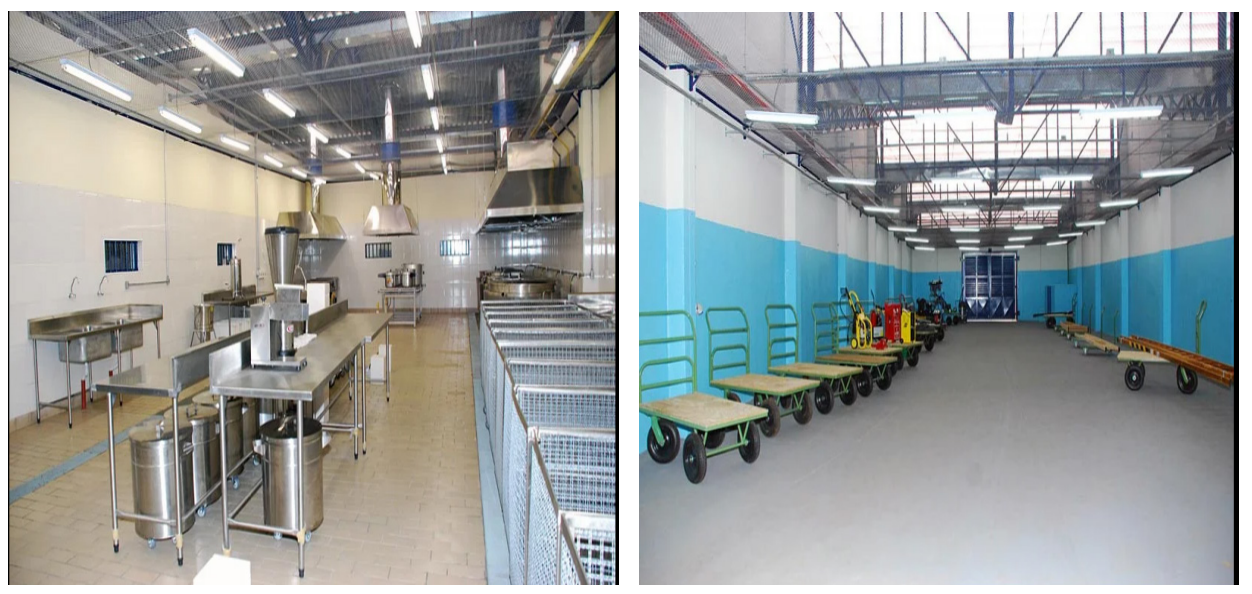

Fonte: Secretaria de Administração Penitenciária

A alimentação dos presos é produzida pelos próprios educandos no setor de cozinha. São duas equipes, uma no período da manhã e outra no da tarde, para produção de café da manhã, almoço e jantar. No Galpão de Trabalho os presos produzem para empresas particulares, como por exemplo, produção de cigarros e sacolas. Os educandos recebem remição tanto por estudar quanto por trabalhar. A cada 3 dias de trabalho/estudo 1 remido. Além disso, o pagamento efetuado pelas empresas particulares forma o que eles chamam de "rateio", ou seja, é uma porcentagem do dinheiro pago pela empresa que é distribuído para todos que trabalham na unidade, independentemente do setor.

Figura 3 - Pavilhão Disciplinar

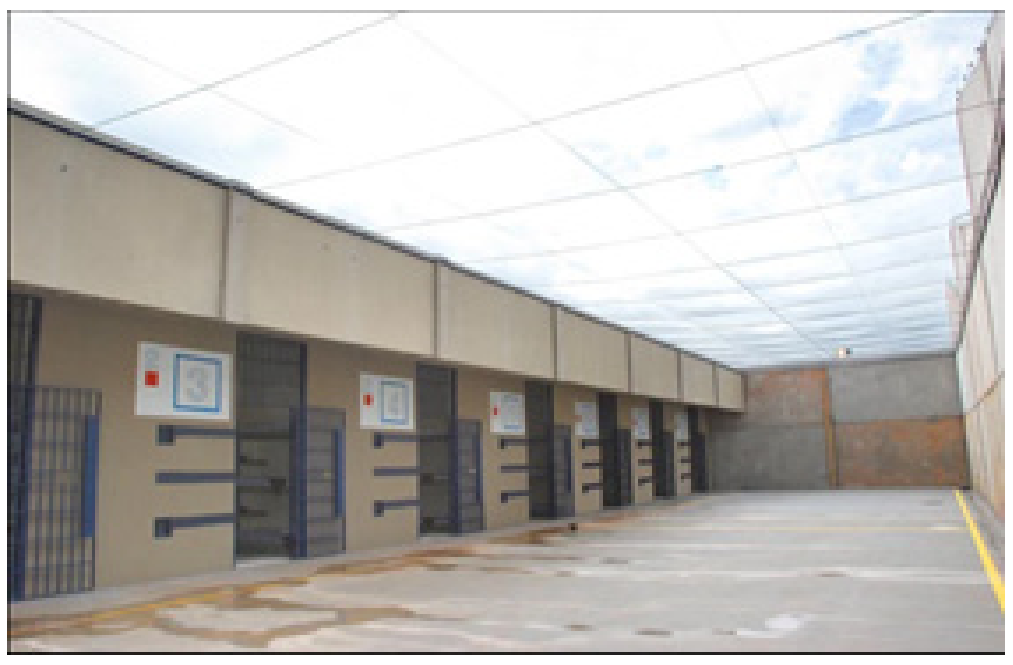

Fonte: Secretaria de Administração Penitenciária 
São oito pavilhões disciplinares, com 8 celas e capacidade para 12 presos em cada cela. Além dos pavilhões superiores de enfermaria e trânsito. As camas são de alvenaria com um colchão em cada espaço. As celas ficam fechadas, são abertas duas vezes ao dia para o banho de sol da manhã e da tarde durante uma hora cada. É possível ter aparelho de televisão na cela, porém deve ser fornecida pela família do preso ou pelo próprio educando.

Com relação ao que é possível ter nas celas, como por exemplo, televisores, rádios, entre outros, há mudanças, restrições e peculiaridades de cada unidade prisional, de acordo com as necessidades e exigências de segurança do local.

Dessa forma, fiz esse breve mapeamento do sistema prisional do Estado São Paulo, como a caracterização do Centro de Detenção Provisória para que seja possível, ao (a) leitor (a), visualizar um pouco da realidade do sistema prisional e do funcionamento de um CDP.

Importante reforçar que nos Centros de Detenção Provisória os presos ainda não possuem condenação, motivo pelo qual optei por este universo de pesquisa, pois como meus objetivos foram os de entender o jovem encarcerado da "Geração Internet" antes e depois de adentrar a prisão, era importante entrevistar este jovem ainda impactado com a entrada no sistema prisional. Além disso, a quantidade de jovens primários e presos provisoriamente é maior do que em outros regimes, o que facilita a possibilidade de encontrar sujeitos de pesquisa.

Outro ponto positivo em relação a escolha do CDP de Serra Azul é o fato de ter sido funcionário da unidade durante 3 anos, período em que trabalhei em vários setores e estabeleci amizade com funcionários que, atualmente, ocupam cargos de direção. Tal fato facilitou 0 acesso a todos os setores da unidade, alguns funcionários "mais antigos" que trabalharam comigo fizeram questão de mostrar todas as mudanças que ocorreram na unidade desde quando eu havia sido transferido para outra unidade há quatro anos.

Vale observar que, tanto os funcionários como os presos, mudam constantemente de unidade prisional. No caso dos presos existem alguns motivos, como por exemplo, cometer uma falta (uso de celular, desobediência às regras da unidade, desrespeito, etc.), progredir de regime, pedir aproximação familiar, ser colocado em liberdade, etc. Já com relação aos funcionários, quando ele assume 0 concurso, é obrigado a escolher a vaga disponível em qualquer lugar do Estado as quais geralmente são longe de suas casas/cidades. Isso faz com que, ao entrar no sistema, o funcionário faça o pedido de transferência para a unidade prisional mais próxima de suas cidades e tenha que aguardar, na unidade que assumiu, a publicação de sua transferência. 
Essa situação de mudança constante de funcionários e presos no sistema prisional, produz unidades prisionais mutantes em que a cada três ou quatro anos, permaneçam apenas alguns funcionários que já estão próximos de suas famílias/cidades ou que constituíram novas famílias a partir de relacionamentos locais; e outros que assumiram cargos de diretoria. Esse cenário engendra uma situação peculiar em que os novos funcionários não conhecem os que passaram nos anos anteriores pelos mesmos locais que estão trabalhando, como aconteceu comigo quando cheguei para coleta dados na unidade de Serra Azul, local que trabalhei durante três anos, mas já fazia cinco anos que não visitava a unidade.

Peço licença ao (a) leitor (a) para colocar uma foto aérea de um CDP Paulista no meio de nosso diálogo. Faço isso porque acredito que será mais fácil de visualizar os caminhos e setores que percorri para fazer a coleta de dados.

Figura 4 - Centro de Detenção Penitenciária

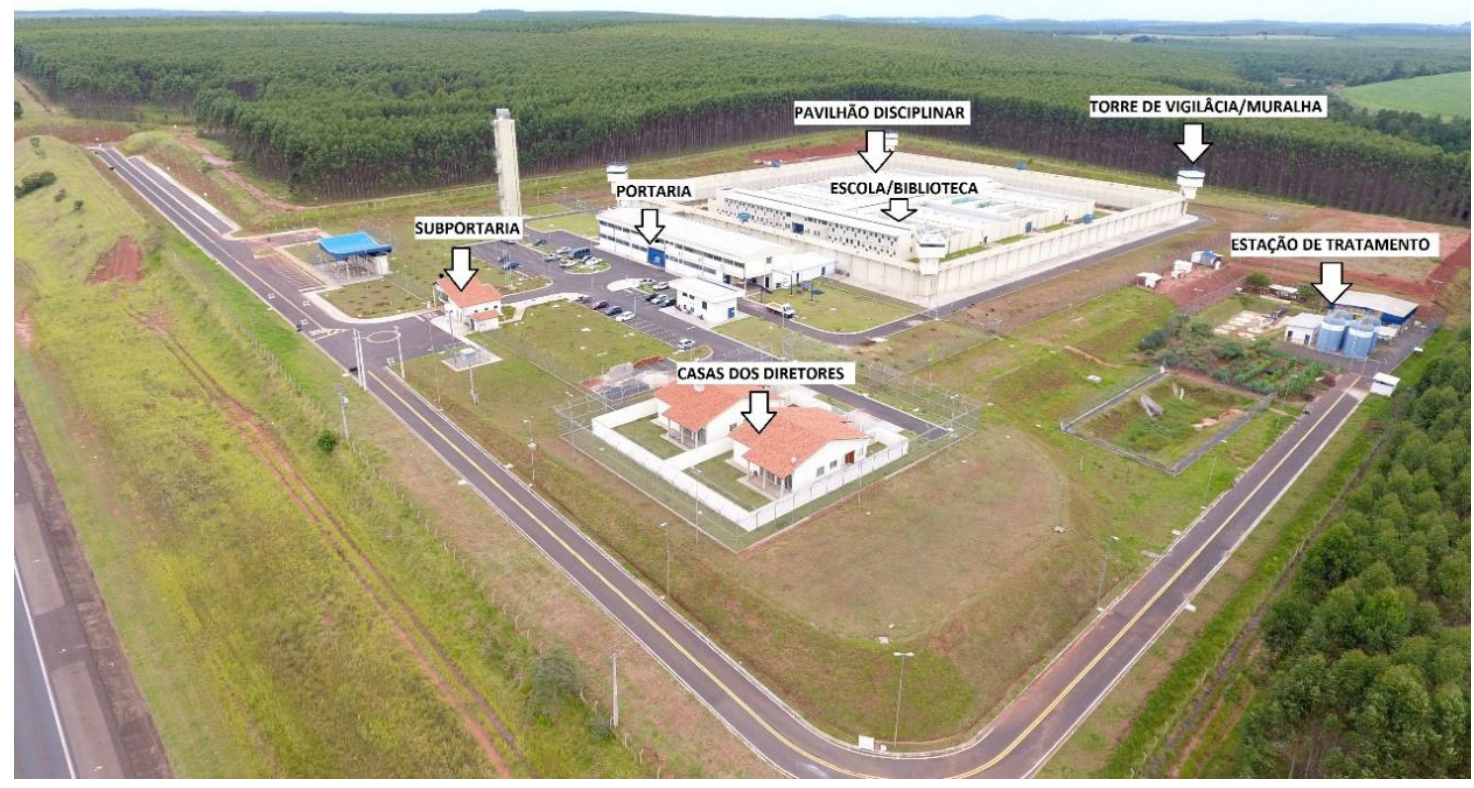

Fonte: Secretaria de Administração Penitenciária

Retomando, cheguei para fazer a coleta e parei o carro na sub portaria. 0 funcionário novo que não me conhecia, perguntou meu nome e não deixou entrar, o que é um procedimento correto de cadeia. Ligou para o diretor de portaria, que me conhece e perguntou a ele sobre mim. 0 diretor de portaria respondeu: "Pode descer". Na portaria, o diretor de portaria me cumprimentou e já havia ligado para o diretor de disciplina perguntando sobre minha autorização para entrar na unidade e o diretor de disciplina confirmou ter recebido a autorização do coordenador e do diretor geral. 
Depois de passar por algumas portas e pela revisora, cheguei à Gaiola 0 (G0), setor que divide 0 acesso a radial (corredor entre os pavilhões) por chapão que só pode ser aberto pelo funcionário. 0 funcionário abriu a ventoinha, que é uma pequena janela de ferro que só é possível enxergar seus olhos. Ele interrogou: "Quem é você?", respondi que estava no local para fazer uma pesquisa. Antes dele fechar a ventoinha novamente, eu interrompi dizendo: "Já trabalhei aí na G0 por quatro meses". Ele sem acreditar pediu que eu repetisse e, ao escutar novamente o relato sobre a experiência no setor que ele estava ocupando, soltou um sorriso e disse: "É um dos nossos".

Na sequência o diretor de núcleo de segurança, que percebeu a movimentação e que era eu que estava na porta proferiu a seguinte frase: "pô.. está segurando o "Cirão" aí meu? esse cara me ensinou a trabalhar". Havia um respeito mútuo entre eu e o referido diretor e tínhamos trabalhado no mesmo setor (Chefia) na época em que estive na unidade.

Em seguida, o diretor de núcleo me levou à sala do diretor de disciplina (que também é da minha época) que me recebeu muito bem, com longos cumprimentos e disponibilidade em ajudar. Falou para o diretor de núcleo dar uma volta comigo na cadeia, momento em que observei todas as mudanças, algumas significativas, como por exemplo, a automatização das portas das celas dos presos, sendo que não era mais necessário ao funcionário entrar no pavilhão com uma chave e um clique na mão, como era na minha época, para trancar os presos. Bastava olhar pelo vidro da gaiola, falar pelo megafone e apertar o botão após o retorno dos presos. 0 diretor mostrou também as instalações e modificações que foram feitas internamente, como por exemplo, no pavilhão de trabalho, na escola, na cozinha e na igreja. Além disso, visitei a biblioteca, na qual estabeleci conversa e contato com a funcionária responsável. 0 diretor de disciplina disponibilizou uma sala com banheiro e mesa, 0 que facilitou a coleta de dados, já que eu pude ficar sozinho com o preso entrevistado, fechar a porta e não ser incomodado.

Tal situação não aconteceria se eu não fosse um "infiltrado", pois com pessoas externas ao sistema, geralmente, seguem o procedimento padrão que é fazer a entrevista no parlatório (setor onde acontece atendimento de advogado, psicólogo, assistente social, oficial de justiça, etc. que separa 0 entrevistador do preso por uma tela de ferro), pois os funcionários são responsáveis pela segurança do entrevistador.

Durante os três dias que permaneci na unidade, não foi necessário mais do que isso pois tive facilidade de acesso aos presos e dados, fui muito bem recebido e tive longas conversas com funcionários da minha época, o que foi ótimo do ponto de vista etnográfico. Só é possível 
entrevistar os presos nos horários do sol da manhã ( $08 \mathrm{~h} 00$ às 10h00) e da tarde (14h00 às 16h00), sendo que eu permanecia nas gaiolas (observando os procedimento e anotava posteriormente) e almoçava com os funcionários, com o cuidado de não deixar ser visto por nenhum preso, já que eles me conheceram como "pesquisador" e o contato próximo com os funcionários poderia dificultar a coleta de dados.

Dessa forma, o Centro de Detenção Provisória de Serra Azul atendeu as minhas expectativas como universo de pesquisa, como havia previsto no momento em que foram formulados os problemas e objetivos de pesquisa, pois pude entrevistar os presos jovens, em um ambiente com pouca ou quase nenhuma interferência externa (sem um funcionário na porta da sala o preso pode falar 0 que ele quiser), podendo permanecer o tempo necessário para realizar a entrevista.

\section{SUJEITOS DE PESQUISA IMERSOS NA DITA “SOCIEDADE DA INFORMAÇÃO”.}

Como foi apresentado no tópico anterior sobre 0 universo de pesquisa escolhido, com os sujeitos de pesquisa utilizei a mesma estratégia, foram escolhidos de acordo com os objetivos, objeto e problema de pesquisa, ou seja, jovens encarcerados com idade entre 18 e 20 anos que supostamente nasceram em meio à "sociedade da informação".

Foram entrevistados 14 jovens que se apresentaram de forma voluntária após um primeiro contato comigo no pavilhão, onde fiz uma breve palestra, expliquei a pesquisa e convidei os sentenciados para participar. Havia grande quantidade de candidatos para serem entrevistados, tendo em vista que há significativa presença de jovens na unidade, e para eles, as entrevistas foram um evento diferente em que eles podiam sair do pavilhão e reclamar para alguém que supostamente não faz parte daquele universo, ou seja, o pesquisador.

No entanto, as entrevistas ficaram restritas a 14 participantes pelo fato de começarem a se repetir e também pelo padrão de funcionamento da unidade em que 0 sentenciado pode ter acesso apenas a alguns dispositivos informacionais, seja no pavilhão 01 ou no 08. As respostas com relação ao uso de TICs antes de adentrar ao sistema prisional tiveram variações devido às múltiplas realidades dos educandos, porém em alguns momentos convergiram pelo fato de serem da mesma idade. Importante salientar que a unidade prisional de Serra Azul estava passando por problemas estruturais desde 2017, quando um dos poços artesianos que alimentam a unidade deixou de funcionar, sendo necessário reduzir a população prisional para 300 sentenciados em média. 
No período em que realizei a pesquisa - fevereiro de 2018 - o poço ainda estava sendo consertado e havia apenas 325 presos. Tal problema não interferiu na realização e coleta de dados, pois não encontrei dificuldades em localizar participantes com as características desejadas pela pesquisa. No que se refere a estudar os sujeitos e suas práticas sociais de produção, apropriação da informação, percebo que são problemáticas essenciais à área e é possível compreender a proposta feita por Naci Nobrega acerca da necessidade de criar um novo eixo temático em que o sujeito é entendido como fonte (NÓBREGA, 2002, p. 69).

De modo geral, tive acesso aos sujeitos que aceitaram participar da pesquisa, assim como houve a colaboração do corpo funcional da unidade. Independentemente de entender os sujeitos como fonte ou como parte do método, é possível afirmar que a compreensão do objeto e das problemáticas da área por meio do contato com os sujeitos é transformadora.

\section{A ENTREVISTA, 0 DIÁRIO DE CAMPO E AS ANOTAÇÕES DO PESQUISADOR}

Neste tópico trago algumas reflexões acerca dos instrumentos de pesquisa utilizados pelo etnógrafo, principalmente a entrevista, o diário de campo e o que chamei de anotações do pesquisador infiltrado. Utilizei os dois primeiros durante a coleta de dados e o último como mecanismo ativo de observação da minha realidade cotidiana.

Dessa forma, inicio tentando conceituar a ideia de entrevista, que pode ser entendida como "[...] um processo que consiste em dirigir à conversação de forma a colher informações relevantes" (ANGROSINO, 2009, p.61). Além de dirigir à conversação, deve o pesquisador criar uma forma de sociabilidade específica, como relata Romanelli (1998):

A entrevista é uma relação didática, que cria uma forma de sociabilidade específica, limitada no tempo, sem continuidade, em que, inicialmente, os parceiros da díade se defrontam como estranhos, pautados para uma alteridade que aparentemente não admite 0 encontro e que deve ser superada para que a matéria prima do conhecimento possa ser produzida durante esse encontro que transforma estranhos em parceiros de troca (ROMANELLI, 1998, p.126)

Essa possibilidade de transformar estranhos em parceiros de trocas, que a entrevista pode oferecer em uma relação limitada de tempo, constitui habilidade essencial do entrevistador, pois é neste momento que o etnógrafo tenta romper as barreiras do estranhamento para que o sujeito possa se sentir livre para o processo de interação.

No ambiente prisional, essa relação deve ser intensificada, pois além do tempo limitado, existe uma série de outras questões envolvidas que podem comprometer a interação do entrevistado com 0 
pesquisador, como por exemplo, desconfiança e sigilo do relato, confiança no entrevistador, limites do que pode ser dito e medo tanto da segurança como das lideranças do crime organizado.

A desconfiança dos educandos é tão explícitas que o simples fato de utilizar um gravador para coletar dados pode ser o maior inibidor de interação e promover o silêncio do sentenciado. A pesquisadora Camila Dias, por exemplo, que não foi autorizada a entrar com o gravador na unidade prisional em que realizou sua coleta de dados, percebeu que o equipamento poderia ter efeito inibidor sobre 0 entrevistado.

Embora minha pretensão inicial fosse realizar entrevistas gravadas, o diretor de segurança e disciplina da P1 (a primeira unidade prisional na qual a pesquisa de campo foi realizada) não autorizou a entrada do aparelho de gravação. Extremamente contrariada com a impossibilidade de captar toda a fala do entrevistado - assim perdendo o fio condutor da narrativa, que engloba os silêncios e hesitações -, fui obrigada a mudar a técnica de captação, utilizando apenas 0 caderno e a caneta para anotar tudo quanto me fosse possível durante a entrevista, complementando com o que ainda estava na memória logo após o seu término. Contudo, com 0 andamento da pesquisa percebi que, embora contrariando minhas pretensões iniciais, 0 gravador poderia ter um efeito inibidor muito forte sobre 0 entrevistado, com impacto decisivo no resultado do trabalho. 0 fato é que, embora sem conseguir captar toda a fala do entrevistado na forma de uma narrativa, com início, meio e fim, com os sons, os silêncios, os risos, as expressões verbais que tanto enriquecem a análise, acabei me adaptando à utilização do caderno de campo para registrar as entrevistas, que passava ao computador tão logo chegava ao hotel, no final da tarde, acrescentando tudo aquilo que não pude registrar de imediato, mas que ainda estava na minha memória (DIAS, 2011, p.36).

No meu caso, já conhecia a rotina de funcionamento da prisão e de antemão optei por não utilizar o gravador, ciente da perdas de narrativas e da impossibilidade de captar os silêncios, os risos e as hesitações proporcionados pela gravação, mas consciente de que os ganhos são muito maiores do que as perdas. Além disso, com a ausência de um objeto que auxilia o instrumento de pesquisa, 0 pesquisador aguça seus sentidos, afina seu diário e fica mais atento a observar os detalhes. Estive a todo momento ciente de que com a ausência da gravação, eu teria que afinar os ouvidos e as anotações, era o pesquisador consigo mesmo, como relata Angrosino (2009):

Frequentemente é dito que o melhor equipamento com que o pesquisador etnográfico pode contar, afinal, é consigo mesmo. Pode-se muito bem entrar em campo com plena carga de câmaras, gravadores, notebooks e assim por diante. Mas, em última análise, observação participante significa que você enquanto pesquisador está interagindo com as pessoas em estudo (ANGROSINO, 2009, p.46).

Sem a gravação, a interação com as pessoas em estudo se potencializou, diminuíram as desconfianças e foi possível de fato praticar a observação participante. 0 ambiente proporcionou essa relação, pois além de ter uma sala em que pude ficar isolado com os educandos, como disse anteriormente, não havia nenhum equipamento eletrônico ou alguma forma de registro no qual pudesse incriminá-los, exceto o meu diário o qual em nenhum momento percebi que os tenha incomodado. 
Dessa forma, ao materializar a fala por meio da escrita, sei que vou poder acessá-la novamente de forma crítica, pois a "[...] escrita torna a fala "objetiva", transformando-a em um objeto de inspeção visual além da inspeção auditiva; é a mudança do receptor do ouvido para os olhos, e do produtor da voz para a mão" (G00DY, 2012, p.57). Embora seja inegável a perda de detalhes, expressões e hesitações que a escrita tem em relação a gravação, ela traz a possibilidade de reviver o fato por meio da memória e, em muitos momentos, visualizar 0 acontecimento. Uma possibilidade de ressignificar o momento dentro das limitações impostas pelo ambiente/campo.

Outra questão extremamente importante em relação a entrevista, é sua limitação como instrumento de pesquisa. A entrevista não pode ser entendida como o principal ou o único mecanismo de coleta de dados, mas apenas como mais um recurso limitado para apreensão da dinâmica social dos indivíduos, como relata Romanelli (1998):

\begin{abstract}
As dificuldades para a utilização da observação têm conduzido pesquisadores de diferentes áreas a privilegiar a entrevista como instrumento básico de coleta de dados. Todavia, os antropólogos têm apontado os limites desse recurso para se aprender os processos e a dinâmica da vida social de grupos urbanos, já que ele captaria apenas as representações de seus integrantes, sendo insuficiente para captar suas formas de conduta (ROMANELLI, 1998, p.124)
\end{abstract}

De acordo com Romanelli, a entrevista capta apenas representações dos integrantes, ou seja, formas de comportamento limitadas e insuficientes para apreensão da conduta social dos indivíduos. Essas representações são facilmente percebidas no ambiente prisional, tendo em vista que é por meio do comportamento que o sentenciado consegue obter algumas "regalias", como por exemplo, trabalhar em setores que existe maior acesso a comida, informações sobre sua pena, etc.

Essas representações vivenciadas em contato com os educandos diariamente na unidade prisional, acontecem principalmente na relação funcionário/preso e sempre foi alvo de inquietação para mim. Deixo aqui a dica ao leitor, tendo em vista os limites de espaço de um artigo, a leitura dos livros de Ervin Goffman, autor que escreveu com riqueza de detalhes como os indivíduos constroem suas representações do eu na vida cotidiana (GOFFMAN, 2014), representações essas que serviram de ferramenta para melhor compreender os indivíduos e a teatralização dos sentenciados no cárcere.

Sem mais delongas, volto a abordar a problemática instrumental da entrevista. Na figura de entrevistador-pesquisador, como foi o meu caso, em que os sentenciados não me conheciam e visualizaram uma possibilidade de "reclamar" e "desabafar", existe o risco de desvio do foco, momento em que a entrevista pode se tornar um grande desabafo, como relata Romanelli (1998): 
Como o pesquisador relaciona-se com o interlocutor de modo específico, não propriamente através do diálogo, mas por intermédio de perguntas, e como não emite julgamentos sobre 0 relato, embora, às vezes, seja solicitado a fazê-lo, o entrevistado sente-se a vontade para expor suas opiniões. Esse desejo de falar de si, inclusive de utilizar a situação de entrevista para desabafo de problemas de ordem pessoal, que nem sequer interessam ao pesquisador, já foi registrado e discutido por Caldeira (1980) e por outros autores. Todavia, a experiência descrita por essa autora refere-se ao relacionamento com sujeitos das classes populares que vêm no interesse do pesquisador o reconhecimento de sua identidade e da importância de suas condições de existência, por alguém socialmente superior a eles e que se dispõe a ouvi-los e a registrar seus depoimentos (ROMANELLI, 1998, p.127).

Assim como a experiência relatada pela pesquisadora Caldeira, em que os sujeitos das classes populares viam na entrevistadora a possibilidade de ter sua identidade reconhecida, na prisão 0 modelo é parecido, os sentenciados veem no pesquisador uma forma de autoridade que não está necessariamente ligada à segurança e disciplina, sendo possível reclamar de tudo, como por exemplo, demora na comunicação com a família e qualidade da comida.

Essas demandas de reclamação e desabafo não podem ocupar um longo tempo da entrevista, mas também não podem ser descartadas e negligenciadas, sendo que é no interior dessa relação que 0 entrevistado reconstrói fatos e acontecimentos que constituíram sua vida. É nesse momento que entra o papel do etnógrafo e sua habilidade em conduzir a entrevista de forma que ela não perca o foco.

Nesse sentido, a forma como a entrevista é conduzida tem papel essencial no processo de coleta e qualidade dos dados. A relação com o entrevistado é construída aos poucos e é a partir dessa construção que surge a possibilidade de avaliar o outro, de promover uma aproximação ou distanciamento de acordo com as necessidades do momento. Assim sendo, o entrevistado não deve ser visto como alguém que apenas responde perguntas, mas como indivíduo que elabora uma identidade para o pesquisador e que produz uma narrativa, muitas vezes, lambuzada de contradições, inconsistências e ambiguidades.

0 entrevistado não é apenas alguém que responde perguntas. Procede-se uma avaliação daquele que pergunta, classifica-o em uma categoria social, organiza os temas, escolhe palavras, compõe sua postura física, adota um estilo descontraído ou formal e, acima de tudo, elabora uma identidade para o pesquisador. Mas esse processo não é representação consciente. No decorrer da relação, ao reconstituir sua história de vida ou simplesmente ao recompor certos acontecimentos, o sujeito reúne fatos que viveu e conhece, fragmentos de eventos que apreendeu; comete indiscrições; abre brechas para novas perguntas. Nessas circunstâncias, 0 fluxo do processo limita a possibilidade de o falante impor um controle rígido sobre seu relato. A organização do depoimento não se traduz em coerência absoluta. Ao contrário, a narrativa assoma carregada de inconsistências, de ambiguidades e de contradições que possibilitam fazer novas perguntas, levantar questões, pedir esclarecimentos (ROMANELLI, 1998, p.130).

Nessa perspectiva, o relato é construído na relação com o entrevistado e cabe ao pesquisador a habilidade de apreender os detalhes, perceber as inconsistências e aproveitar as brechas para inserir 
novos assuntos e conduzir o relato para as questões de pesquisa. Além disso, o etnógrafo deve ter 0 cuidado de não tomar o relato do entrevistado como único ponto de vista ou caminho a ser trilhado.

Esse risco é bastante comum em um ambiente prisional, tendo em vista que o pesquisador ao adentrar a prisão fica deslumbrado após ter contato com o sentenciado. Ao entrevistador é necessário compreender o relato do outro como uma interpretação êmica, ou seja, como parte de um conjunto de explicações do segmento ao qual o sujeito está inserido, tendo caráter coletivo e não individual. Nessa lógica, a “[...] interpretação êmica não pode substituir a análise ética que deve ser produzida empiricamente pelo antropólogo" (ROMANELLI, 1998, p.131).

Além da entrevista, o diário de campo também é instrumento essencial do método etnográfico, pois é por meio dele que o pesquisador registra toda sua experiência e imersão no campo, sendo possível registrar detalhes tanto do universo de pesquisa como dos traços e comportamentos culturais de um grupo social. 0 diário de campo é um dos principais ofícios do etnógrafo: "[...] parte expressiva do ofício do etnógrafo reside na construção do diário de campo. Esse é um instrumento que o pesquisador se dedica a produzir dia após dia ao longo de toda a experiência etnográfica (WEBER, 2009, p.158)”.

Dessa forma, o diário de campo exige disciplina e dedicação diária e é responsável por acumular materiais para analisar as práticas e os discursos dos entrevistados, sendo possível posteriormente compreender melhor os observados, como revela Weber (2009):

É no diário de campo que se exerce plenamente a "disciplina" etnográfica: deve-se aí relacionar os eventos observados ou compartilhados e acumular assim os materiais para analisar as práticas, os discursos e as posições dos entrevistados, e também para colocar em dia as relações que foram nutridas entre 0 etnógrafo e os pesquisados e para objetivar a posição de observador. É, pois, o diário de pesquisa de campo que permitirá não somente descrever e analisar os fenômenos estudados, mas também compreender os lugares que serão relacionados pelos observados ao observador e esclarecer a atitude deste nas interações com aqueles (WEBER, 2009, p.159).

No meu caso, o diário de campo foi instrumento que me acompanhou durante toda a coleta, mesmo em momentos em que os presos estavam trancados, ou nos minutos entre uma entrevista e outra, não deixei de registrar os acontecimentos e as peculiaridades culturais dos entrevistados e do local. 0 momento de maior importância para mim com relação ao diário de campo foi quando chegava em casa, período em que utilizava para anotar as lembranças das conversas, comportamentos e detalhes que estavam frescos na memória.

Como uma colcha de retalhos, meu diário de campo foi sendo compilado sem uma lógica aparente, entre cópias e transcrições de dados anunciados por outros, em que no final tentei juntar as informações e analisar o sentido. Apoiado em um corpo teórico e tentando perceber os detalhes para 
que seja possível escolher os fatos significativos, o trabalho antropológico pode ser visto como arte, como relata Romanelli (1998):

\begin{abstract}
Observação e indagação, ainda que intimamente e aparentemente completas, são totalmente inúteis a menos que estejam baseadas num corpo teórico. Outra reporta-se ao fato de que a pesquisa antropológica é um trabalho artesanal que, segundo Evans- Pritchard (1969, p. 108), deve ser considerado como uma arte e não como uma ciência. Ainda segundo esse autor, o trabalho de campo não consiste em fotografar, mas em escolher fatos significativos, 0 que só pode ser apreendido com experiência. Mas, além de um amplo conhecimento de antropologia, é necessário ter capacidade para observar formas e estruturas, o que pressupõe certa genialidade. É nesse sentido que Evans-Pritchard (1969, p.105) compara o trabalho do antropólogo com o do artista, esclarecendo que o primeiro deve ter talento literário para traduzir uma cultura estrangeira em sua própria língua, decifrando, desse modo, o sistema simbólico da sociedade estudada (ROMANELLI, 1998, p.125).
\end{abstract}

Independentemente do trabalho etnográfico ser enxergado como um retrato social ou como um trabalho artístico de cunho literário que seja capaz de traduzir a cultura de um grupo social, 0 fato é que os instrumentos de pesquisa, principalmente o diário de campo é condição "sine qua non" para que o trabalho etnográfico possa existir. Além disso, são instrumentos que auxiliam na produção de materiais provocativos que servem para repensar a realidade social, como relata Durham: "[...] 0 trabalho altamente descritivo da antropologia, sua capacidade de detectar perspectivas divergentes e interpretações alternativas, apresenta um material provocativo e estimulante para repensar a realidade social" (DURHAM, 1973, p.19).

\title{
6 ANOTAÇÕES DO PESQUISADOR INFILTRADO
}

Durante o processo de coleta de dados decidi criar um instrumento de pesquisa que intitulei "Anotações do pesquisador infiltrado" e foi fruto de reflexão teórica acerca dos limites dos instrumentos de pesquisa, da reduzida permanência do pesquisador na prisão e das dificuldades em realizar observação participante no ambiente prisional, tanto por questões de dificuldade de acesso, como por demandas de segurança.

Após fazer a minha coleta de dados, que realizei no CDP de Serra Azul, fiquei com a sensação de impotência dessas informações, pois por mais que a unidade tenha sido bastante receptiva e proporcionado ambiente fechado e adequado para que eu pudesse realizar a entrevista e interagir com o preso, o contato é pequeno e fora do ambiente de convívio dos educandos. Mesmo que não concorde inteiramente com Malinowski, pensei em seus relatos sobre dados observados do comportamento real: 
Se todas as conclusões forem apenas baseadas nos relatos dos informantes ou deduzidas a partir de documentos objetivos, torna-se claramente impossível atualiza-las com dados efetivamente observados do comportamento real. E esta é a razão pela qual determinados trabalhos de amadores residentes a longo prazo - como comerciantes e trabalhadores instruídos, médicos e administrativos e, claro está, alguns dos missionários inteligentes e sensatos aos quais a Etnografia tanto deve - ultrapassam em plasticidade e riqueza vivencial da maior parte dos relatórios puramente científicos (MALINOWSKI, 1997, p.30).

É possível discordar facilmente da visão funcional de Malinowski, principalmente quando penso na visão de "ser interpretante" de Geertz, porém não posso negligenciar o fato de que a vivência mais duradoura com os sujeitos de pesquisa traz uma infinidade maior de elementos para serem observados e analisados. Nesse sentido, pensei que poderia expandir os limites do meu universo de pesquisa, ou seja, o Centro de Detenção Provisória de Serra Azul para continuar minha observação participante no Centro de Progressão Penitenciária (Regime semiaberto), unidade que trabalho.

Tal proposta pode ser questionada pelo fato de serem unidades com tipos de regime de cumprimento de pena diferentes, sendo o CDP de Serra Azul "regime provisório" e o Centro de Progressão Penitenciária "regime semiaberto", porém o comportamento do sentenciado é parecido em ambos os regimes. Além disso, a maioria dos presos passam tanto pelo regime provisório como pelo semiaberto, tanto que encontrei alguns meses depois, no Centro de Progressão Penitenciária, sujeitos que participaram das minhas entrevistas no CDP de Serra Azul. 0 comportamento "padrão" dos presos e meus sentimentos de incompletude, fizeram com que eu criasse as "Anotações de pesquisador infiltrado".

Pelo fato de ser agente penitenciário e participar diariamente das atividades com os presos, como por exemplo, organizar a estrutura de estudo da unidade que consiste em entrevistar os presos e direcioná-Ios para atividade de educação tanto no ensino regular como cursos, mediar os encontros do clube de leitura, auxiliar na instrução e capacitação dos presos para funcionamento da biblioteca, entre outras atividades, pensei que poderia continuar minha observação participante no ambiente de trabalho.

Dessa forma, com o aporte teórico da etnografia, passei a realizar minhas atividades na unidade prisional tentando, em muitos momentos, fazer uma observação guiada pela pergunta de pesquisa para construção das minhas anotações do pesquisador. Ciente dos limites dessa observação e da condição de funcionário da prisão que, de alguma maneira, pode inibir o preso de uma maior interação, tentei me ater aos detalhes. 
A técnica do pesquisador infiltrado consiste em anotar as situações e acontecimentos que marcaram minha vivência diária na unidade e que possa contribuir com minhas perguntas de pesquisa. Essas anotações foram feitas, principalmente, quando chegava em casa após o trabalho, ainda que algumas dessas anotações tenham acontecido durante 0 expediente. As "Anotações do pesquisador infiltrado" potencializaram meus dados e auxiliaram no processo de compreensão do objeto de pesquisa. Elas contribuíram para um melhor entendimento acerca do que ocorre em lugares considerados desconhecidos como a prisão.

A exigência de atenção de um relatório etnográfico não repousa tanto na capacidade do autor de captar os fatos primitivos em lugares distantes e levá-los para casa como uma máscara ou um entalho, mas no grau em que ele é capaz de esclarecer o que ocorre em tais lugares, para reduzir a perplexidade - que tipos de homens são esses? - a que naturalmente dão origem os fatos não familiares que surgem de ambientes desconhecidos (GEERTZ, 2015, p.12).

Nesses "ambientes desconhecidos", como é o caso da prisão, em que a maioria da sociedade e a imprensa tanto emitem opiniões e julgamentos e, em muitos casos, desconhecem seu funcionamento, talvez a contribuição das "anotações do pesquisador infiltrado" possa reduzir a perplexidade sobre quais tipos de homens são esses que se encontram no ambiente prisional.

\section{COLETA, AMOSTRAGEM, SATURAÇÃO E FORMAS DE ANÁLISE DOS DADOS}

Neste tópico tento detalhar o percurso que segui para conseguir realizar a coleta na unidade prisional e aponto 0 momento em que entendi que os dados atingiram o grau de saturação, além disso, faço algumas reflexões acerca das formas de análise de dados. Logo no final do primeiro ano de doutoramento, submeti o projeto ao Comitê de Ética e Pesquisa da Secretaria de Administração Penitenciária (SAP) e em seguida, após receber anuência do secretário da SAP, Sr. Lourival Gomes, 0 encaminhei à plataforma Brasil que emitiu parecer favorável no final do segundo ano de pesquisa.

De posse da autorização, iniciei contato com a unidade prisional para realização da coleta. Entretanto, fui informado sobre a situação pelo qual estava passando o CDP de Serra Azul, ou seja, um problema no poço de abastecimento de água fez com que a população prisional que era de quase mil sentenciados estivesse funcionando com trezentos.

Decidi aguardar e pensei em alterar o universo de pesquisa, tendo em vista que talvez, com a população reduzida, não seria possível encontrar os sujeitos adequados ao problema de pesquisa, ou seja, jovens entre 18 e 20 anos. Porém, após novos contatos com o diretor da unidade e sua afirmação 
de que seria possível encontrar os sujeitos desejados mesmo com a população reduzida, decidi iniciar a coleta.

Como fui muito bem recebido e consegui realizar a entrevista em local adequado, a coleta ocorreu com qualidade. Inicialmente passei nos pavilhões explicando a pesquisa e a ausência de obrigatoriedade em participar, sendo a participação totalmente voluntária. Fiquei surpreso com a predisposição dos sentenciados em colaborar com a pesquisa. Durante os três dias de coleta, cheguei antes das oito da manhã e deixei o local no final da tarde.

Os sentenciados foram retirados do pavilhão pelo funcionário da prisão e encaminhados à sala em que realizei a entrevista. A sala era pequena, porém havia uma mesa, cadeira e privacidade para conversar sem intervenção externa. Ao receber o preso, eu fechava a porta, o cumprimentava e explicava a pesquisa e os motivos pelos quais iríamos conversar durante quase uma hora. Após 0 cumprimento, a acomodação na cadeira com a porta fechada e a ausência de gravadores, os jovens se sentiam livres para falar e mantivemos diálogos bastante proveitosos.

Todos os entrevistados foram orientados sobre o Termo de Consentimento Livre e Esclarecido (TCLE) e receberam uma cópia do mesmo após assiná-lo. Além disso, alertados sobre a garantia do anonimato de seus nomes e que eles seriam identificados por siglas durante a escrita do trabalho, 0 que diminuiu a relação de desconfiança. De forma breve, utilizei questionário sociodemográfico para fazer um mapeamento da situação social dos educandos e, em seguida, a entrevista semiestruturada, para, dentro do limite do tempo permitido pela unidade prisional, não perder o foco e conduzir a entrevista com o objetivo de extrair informações específicas:

\begin{abstract}
Embora a entrevista etnográfica clássica seja de natureza aberta [...] também é possível conduzir entrevistas semiestruturadas, que usam perguntas predeterminadas relacionadas a "campos de interesse" (p. ex., "De que maneira as pessoas ganham a vida nesta aldeia?","Que tipos de programas comunitários estão disponíveis para adultos desospitalizados com retardo mental?"). Ao contrário da entrevista aberta, que pode rondar livremente a área delineada pelas questões gerais de pesquisa, a entrevista semiestruturada segue de perto o tópico escolhido de antemão e apresenta questões destinadas a extrair informação específica sobre aquele tópico (ANGROSINO, 2009, p.67).
\end{abstract}

Optei pela entrevista semiestruturada apenas para não sair da rota delineada anteriormente pelo problema de pesquisa, porém ao longo da conversa, muitos assuntos surgiram e foram feitas questões abertas que trouxeram riquezas de detalhes as informações coletadas. Foram entrevistados quatorze sentenciados de idade entre 18 e 20 anos e nenhum se recusou a responder as perguntas ou manifestou interesse em interromper a entrevista. Inicialmente minha proposta era de entrevistar 
aproximadamente 30 jovens, porém percebi que o quadro empírico da pesquisa já estava sendo mapeado e compreendido a partir do décimo entrevistado, formando uma amostra articulada com a escolha do grupo e a dimensão do objeto (MINAYO,2017, p.03).

Essa questão do tamanho da amostra e do conceito de saturação dos dados é bastante contestada entre os pesquisadores, o que gera divergências entre eles, como relata Minayo (2017):

\begin{abstract}
Vários dos pesquisadores [...] questionam os parâmetros epistemológicos para aplicação do conceito de saturação, arriscam-se a propor algum critério quantitativo para a abordagem dos entrevistados em campo. (GUEST; BUNCE; JOHNSON, 2006; MORSE, 2000, 2008; HARVEY, 2000) mencionaram que os trabalhos de etnografia, etnociência e avaliação qualitativa devem contemplar entre 30 a 50 entrevistas. Creswell (1998) fala da mesma quantidade para os estudos de teoria fundamentada. Cresswell (1998) e Morse (1994) propõem que as pesquisas de cunho fenomenológico se atenham a no máximo 25 e a no mínimo a cinco entrevistas. Para a pesquisa de histórias de vida, 15 seria um número mínimo aceitável para Bertaux (1981). Em resumo, uma quantidade consensual seria de, pelo menos, 20 a 30 entrevistas para qualquer tipo investigação qualitativa, segundo Morse (1994) e Creswell (1998). Atran, Medin e Ross (2005) falam de no mínimo 10 informantes (MINAYO, 2017, p.06).
\end{abstract}

Como é possível perceber, não existe um consenso entre os pesquisadores sobre o tamanho da amostra, ou da quantidade de entrevistados necessários para desenvolver um estudo qualitativo. Concordo com a opinião, exposta por Minayo (2017), acerca dos pesquisadores qualitativos mais experientes que não trabalham com o conceito de saturação em mente, mas que pensam apenas em dar corpo a sua pesquisa e torná-la defensável à luz das teorias que fundamentam suas indagações:

[...] preocupam-se menos com a generalização e as generalidades e mais com o aprofundamento, a abrangência e a diversidade no processo de compreensão, seja de um grupo social, de uma organização, de uma instituição, de uma política ou de uma representação, colocando esses diferentes aspectos à luz das teorias que fundamentam suas indagações. Seu critério principal não é numérico, embora quase sempre precise justificar a delimitação da multiplicidade das pessoas que vai entrevistar e a dimensão e escolha do espaço (MINAYO, 2017, p.10).

Esses critérios não numéricos e focados no processo de compreensão do grupo social em questão, ou seja, os jovens encarcerados, me levou a interromper as entrevistas e encerrá-las com quatorze participantes. Além disso, percebi a repetição das respostas com relação às questões vinculadas ao uso das TICs, tanto antes como após adentrarem ao ambiente prisional.

Após fazer a coleta e limitar a amostra por meio do conceito de saturação, faço reflexão acerca das formas de análise de dados etnográficos. Segundo Angrosino a análise de dados etnográficos pode parecer mais uma arte do que uma ciência, porém o autor pondera que há mais regularidade em suas abordagens do que parece (ANGROSINO, 2009). De fato, percebi essas regularidades após fazer uma "leitura panorâmica" das minhas anotações. Em seguida separei os dados em categorias que foram analisados e apresentados nos capítulos de resultados da tese. 
Para melhor visualização dos dados tanto para o pesquisador como para 0 (a) leitor (a), elaborei quadros com as respostas obtidas no questionário sociodemográfico e nas entrevistas, 0 que proporcionou a possibilidade de fazer comparações e perceber as regularidades e assuntos que permearam os discursos dos jovens. Para isso, utilizei duas formas principais de análise, ou seja, a "análise descritiva" que é o processo de tomar o fluxo de dados e decompô-lo em suas partes constitutivas; em outras palavras, perceber quais padrões, regularidades ou temas emergem dos dados. E a "análise teórica" que é o processo de descobrir como aquelas partes componentes se encaixam; em outras palavras como é possível explicar a existência de padrões nos dados, ou como decifrar as regularidades percebidas (ANGROSINO, 2009).

Ambas as formas de análise, tanto a descritiva como teórica, foram vitais para compreensão e composição textual analítica dos dados, pois elas permitem um mapeamento e a junção de anotações "dispersas", além de promover a visualização do todo, o que proporcionou ao trabalho do pesquisador um aproveitamento mais amplo e sistemático dos dados coletados.

\section{CONSIDERAÇÕES FINAIS}

Por meio de narrativas tentei demonstrar como foi trabalhar com o método etnográfico na prisão, apontando durante todo o texto, seus limites e potencialidades. Tal proposta se faz necessária tanto para provocar novas pesquisas na área de $\mathrm{Cl}$ com relação a temática prisional ampliando 0 escopo do campo, como para revelar ao leitor o leque imenso de possibilidades de atuação para 0 profissional bibliotecário no cárcere.

Nesse sentido, compreender como foi a aplicação dos instrumentos, os questionamentos que surgiram ao longo do estudo, a escolha de um universo de pesquisa em detrimento de outros, a seleção de sujeitos, os desafios para realizar a entrevista e a coleta de dados, são descrições essenciais para incentivar novos pesquisadores a utilizarem o método e adentrarem ao espaço prisional.

Tentei evidenciar o fato de o cárcere ter suas próprias regras de funcionamento e que é necessário encontrar mecanismos e ferramentas que consigam apreender ao máximo a realidade socialmente vivida, tendo em vista as limitações do método, ou seja, há um distanciamento de percepção em vivenciar o cárcere entre o pesquisador e a pessoa que está em situação de privação de liberdade. Ainda assim, relatei ao leitor que é possível, mesmo na posição de pesquisador, mergulhar no universo de pesquisa como um "ser interpretante". 
Por fim, trabalhar com etnografia é extremamente gratificante e traz resultados que tendem a desorganizar a episteme de qualquer área, pois o método vai a campo e oferece novas perspectivas e olhares. Além disso, é um método que pode ser aplicado em múltiplos ambientes sendo possível observar e descrever uma infinidade de processos culturais e suas interações sociais. Portanto, é evidente e necessário o constante diálogo entre pesquisas etnográficas e o campo da Ciência da Informação para poder sempre visualizar o novo ou o desconhecido.

\section{NOTA EXPLICATIVA}

Esse artigo é parte da tese "Informação encarcerada: 0 jovem da geração internet e a mediação e apropriação dos dispositivos informacionais no interior da prisão" que foi orientada pelo professor Dr. Oswaldo Francisco de Almeida Júnior.

\section{REFERÊNCIAS}

ANGROSINO, M. Etnografia e observação participante. Porto Alegre: Artmed, 2009.

ARAUJO, Carlos Alberto Ávila. Teoria crítica da informação no Brasil: a contribuição de Armand Mattelart. RECIIS. Revista eletrônica de comunicação, informação \& inovação em saúde (Edição em português. Online), v. 3, p. 112-119, 2009. Disponível em: https://www.reciis.icict.fiocruz.br/index. php/reciis/article/view/786\#: :text=S\%C3\%A30\%20destacadas $\% 2 C \% 20$ em $\% 20$ particular $\% 2 C \% 20$ suas, de $\% 20 \%$ E2\%80\%9Csociedade $\% 20$ de $\% 20$ informa $\%$ C3\%A7\%C3\%A30\%E2\%80\%9D. Acesso em: 14.02.2020.

BOFF, Leonardo. A Águia e a galinha: uma metáfora da condição humana. 16 ed. Petrópolis, RJ: Vozes, 1998.

CUNHA, M. Ivone. Etnografias da prisão: novas direções. Configurações, vol. 13, pp. 4768, 2014. Disponível em: http://repositorium.sdum.uminho.pt/bitstream/1822/32367/1/ EtnografiasPris\%c3\%a30.pdf . Acesso em: 25.03.2020.

DEXTER. 0 destino do réu. Flor de lótus. São Paulo: Dexter, 2016. Disponível: https://www.youtube. com/watch?v= NA2gujNYKg. Acesso: 20.12.2019.

DIAS, Camila Nunes Caldeira. Da pulverização ao monopólio da violência: expansão e consolidação do Primeiro Comando da Capital (PCC) no sistema carcerário paulista. 2011. $355 f$. (Doutorado em Sociologia) - Faculdade de Filosofia, Letras e Ciências Humanas da Universidade de São Paulo, 2011. Disponível em: https://www.teses.usp.br/teses/disponiveis/8/8132/tde-13062012164151/publico/2011_CamilaCaldeiraNunesDias_VOrig.pdf . Acesso em: 23.01.2020.

DURHAM, Eunice. R. A reconstituição da realidade: um estudo sobre a obra etnográfica de Bronislaw Malinowski. Tese. (Livre-Docência). Departamento de Ciências Sociais da FFL e CH da Universidade de São Paulo, 1973. 
GEERTZ, Clifford. A interpretação das culturas. - 1ª ed. - Rio de Janeiro: LTC, 2015.

GOFFMAN, Erving. A representação do eu na vida cotidiana; tradução de Maria Célia dos Santos Raposo. Petrópolis: Vozes, 2014.

GOFFMAN, Erving. Manicômios, Prisões e Conventos. São Paulo: Editora Perspectiva,1974.

G00DY, Jack. A domesticação da mente selvagem; tradução de Vera Josvelyne. Rio de Janeiro: Petrópolis, 2012.

MAGNANI, José Guilherme Cantor. Etnografia como prática e experiência. In: Horizontes

Antropológicos. Porto Alegre, ano 15, n.32, jul/dez de 2009, p. 129-156. Disponível em: https://www. scielo.br/pdf/ha/v15n32/v15n32a06.pdf . Acesso em: 15.02.2020.

MAGNANI, José Guilherme Cantor. De perto e de dentro: notas para uma etnografia urbana. Revista Brasileira de Ciências Sociais, v. 17, n. 49, p. 11-29, 2002. Disponível em: http://nau.fflch.usp.br/ files/upload/paginas/de_perto_de_dentro_0.pdf . Acesso em: 20.03.2020.

MALINOWSKI, Bronislaw. Argonautas do Pacífico Ocidental: um relato do empreendimento e da aventura dos nativos no arquipélagos de Nova Guiné melanésia. São Paulo: Editora Abril Cultural, 1978.

MALINOWSKI, Bronislaw. Um diário no sentido estrito do termo. Rio de Janeiro/São Paulo: Record, 1997.

MINAYO, Maria Cecília de Souza. Amostragem e saturação em pesquisa qualitativa: consensos e controvérsias. Revista Pesquisa Qualitativa. São Paulo (SP), v. 5, n. 7, p. 01-12, abril. 2017. Disponível em: https://editora.sepq.org.br/index.php/rpq/article/view/82 . Acesso em: 18.01.2020.

NÓBREGA, Nanci Gonçalves da. Conjugando o gerúndio: antropologia da informação e leitura percursos de leitor. 2002. Tese (Doutorado em Ciência da Informação) - Universidade Federal do Rio de Janeiro, Rio de Janeiro: Ibict/MCT, 2002.

ROMANELLI, G. A entrevista antropológica: troca e alteridade. In: Geraldo Romanelli; Zélia Maria Mendes Biasoli Alves. (Org.). Diálogos metodológicos sobre prática de pesquisa. $1 f$ ed. Ribeirão Preto-SP: Ed. Legis Summa Ltda, 1998, p. 119-133.

SAMAIN, Etienne Ghislain; ECKERT, C. Ver e Dizer na Tradição Antropológica. Bronislaw Malinowski e a Fotografia. HORIZONTES ANTROPOLÓGICOS, PORTO ALEGRE, v. 2, p. 19-48, 1995. Disponível em: http://www.cchla.ufpb.br/etienne_samain_unicamp/wp-content/uploads/2018/01/Samain-1995-Ver-edizer-Malinowski.pdf . Acesso em: 10.03.2020.

SCOTT, David. Critical Research Values and C. Wright Mill's Sociological Imagination: Learning Lessons from Researching Prison Officers. Frauley, Jon. Ed. C. Wright Mill's and the Criminological Imagination. Prospects for Creative Inquiry. New York: Routledge, capítulo VIII, pp. 185-189, 2016.

SPIVAK, Gayatri Chakravorty. Pode o subalterno falar? Belo Horizonte: Editora UFMG, 1985.

WEBER, Florence. A entrevista, a pesquisa e o íntimo, ou: por que censurar seu diário de campo? Horizontes Antropológicos, Porto Alegre, ano 15, n. 32, p. 157-170, jul./dez. 2009. 229 Disponível em: https://www.scielo.br/scielo.php?script=sci_arttext\&pid=S0104-71832009000200007\&Ing=en\& nrm=iso . Acesso em: 20.12.2019. 